determination of the obscenity of challenged publications would alleviate the situation considerably. ${ }^{84} \mathrm{~A}$ wider use, at the first sign of police opposition, of the declaratory judgment procedure now available in many states or of the "quasi-in-rem equity" proceeding with which Massachusetts is experimenting ${ }^{85}$ would be desirable. Either procedure immediately brings the publisher into court to defend his books and tends to discourage police censors from attacking his publications.

\footnotetext{
\& The same technique has been applied to a similar problem of police activity-is a machine a game of skill or of chance? Thrillo, Inc. v. Scott, 15 N.J. Super. 124, 82 A. 2d 903 (1951).

${ }^{85}$ Mass. Stat. Ann. (Supp., 1953) c. 272, § 28(C)-(G). Consult Attorney General v. Book Named "Forever Amber," 323 Mass. 302, 81 N.E. 2d 663 (1948). This Massachusetts procedure is a modified version of a declaratory judgment. It is technically against the book, and binds not only those present before the court but all future sellers of the book.
}

\title{
SECTION 3 OF THE CLAYTON ACT-"LAW UNTO ITSELF"
}

Proponents of theories of pure competition frowned on agreements to deal with a single seller as being unduly restrictive both of the right to buy where one pleased and the right to compete freely for the business of all buyers. ${ }^{1}$ Such theory was apparently responsible for the passage of Section 3 of the Clayton Act. The relevant provisions are:

It shall be unlawful for any person engaged in commerce ... to lease or make a sale or contract for sale of goods ... or other commodities, whether patented or unpatented . . . or fix a price, charged therefor, or discount from, or rebate upon, such price, on the condition, agreement or understanding that the lessee or purchaser thereof shall not use or deal in the goods ... of a competitor or competitors of the lessor or seller, where the effect of such lease, sale, or contract for sale or such condition, agreement, or understanding may be to substantially lessen competition or tend to create a monopoly in any line of commerce. ${ }^{2}$

The "where-the-effect" clause of this section has been, as was anticipated in the congressional debates, difficult for the courts to interpret. The statement in United States v. Standard Oil Co. (Standard Stations) 3 that "the qualifying clause of Section 3 is satisfied by proof that competition has been foreclosed in a substantial share of the line of commerce affected" was thought to settle the criterion by which exclusive-dealing agreements would be declared illegal. Since then, however, this decision has been subjected to analysis and attack by the commentators, to interpretation by the lower courts

${ }^{1}$ Consult Stevens, Unfair Competition 91 (1917); Clark and Clark, How to Control Trusts 98-103 (2d ed., 1912).

238 Stat. 731 (1914), 15 U.S.C.A. \$ 14 (1951).

${ }^{3} 337$ U.S. 293, 314 (1949). 
and to an extended dictum in the Supreme Court. This comment will attempt to evaluate, in the light of the legislative background of the Clayton Act, the effect of later decisions on the standard of legality for exclusive dealing.

The Clayton Act, when first introduced in Congress, contained an absolute prohibition of exclusive dealing and prescribed criminal penalties for its violation. It passed the House in substantially unchanged form. In the Senate, however, the sections on exclusive dealing and price discrimination were stricken. ${ }^{4}$

Because of the conflict between the House and Senate versions, the bill was sent to conference. When it emerged, the prohibitions against price discrimination and exclusive dealing had been restored, but the clause specifying criminal penalties had been dropped. To both sections there had been added the clause, "where the effect of such lease, sale, or contract for sale . . may be to substantially lessen competition or tend to create a monopoly in any line of commerce." The elimination of the criminal penalties, combined with the addition of language that theretofore had appeared only in Section 7, caused extended debate in both houses. ${ }^{5}$ The comments shed some light on what Congress thought it was outlawing when it passed the Clayton Act.

In the House, Representative Floyd explained that the addition was caused by the elimination of the criminal penalties:

After the penalties were sticken out, the provisions of sections 2 and 3 were modified, because as criminal sections they were drafted with all the particularity of criminal statutes, the intent and purpose being included. But that is not the rule applicable to contracts... . [A] modification was made in harmony with principles governing the construction and interpretation of contracts. ${ }^{6}$

Mr. Floyd went on to explain that the new language had evolved from the Supreme Court's opinion in Addyston Pipe \& Steel Co. v. United States. ${ }^{7}$

The reason for striking was the sweeping prohibition of "unfair methods of competition" in Section 5 of the Federal Trade Commission Act, which had just been passed. 38 Stat. 719 (1914), as amended, 15 U.S.C.A. $\$ 15$ (1951). In addition, some senators felt that the Clayton Act's absolute prohibition was too stringent and that the Federal Trade Commission could better determine whether the use of exclusive dealing did, in the particular instance, adversely affect competition. 51 Cong. Rec. 14,267, 14,272-73, 14,098 (1914).

${ }^{5}$ In the Senate, ibid., at $15,830,15,856$ et seq. In the House, ibid., at 16,317 et seq.

- Ibid., at 16,317. Logically, the elimination of the criminal penalties would have eliminated the need for proof of intent and purpose, so that no additional language would have been needed. Apparently, however, the Congressman's understanding was otherwise.

${ }^{7} 175$ U.S. 211 (1899), a horizontal combination case. The Court was faced with the contention that the commerce clause of the Constitution was intended only to prevent the states from placing restrictions on interstate commerce and not to empower Congress affirmatively to regulate commerce. Ibid., at 227. In addition, the defendant urged that contracts not designed, at the time they were made, to create impediments to interstate commerce could under no circumstances be regulated by Congress. Ibid. Both contentions were rejected by the Court with the statement in the text. 
The Court had there stated that

the power of Congress to regulate interstate commerce comprises the right to enact a law prohibiting the citizen from entering into those private contracts which directly and substantially, and not merely indirectly, remotely, incidentally, and collaterally, regulate to a greater or less degree commerce among the States. ${ }^{8}$

In the above quotation, the word "substantially" was not used in a quantitative sense, i.e., it did not relate to the extent of regulation. ${ }^{9}$ No quantitative antonym of "substantially" appears in the sentence; rather, it was used in the sense of "in reality" regulating commerce. The quantum of regulation needed was specifically covered by the phrase "to a greater or less degree."10 Since the principle embodied in the qualifying clause of Section 3 was taken from the Addyston Pipe case, "substantially" could similarly be read with no quantitative connotation in the qualifying clause. The clause, then, could be interpreted as having been intended only to remove the necessity for proof of intent and purpose ${ }^{11}$ and as prohibiting exclusive-dealing contracts whenever the effect of such a contract was to regulate commerce.

Unfortunately, the congressional debates do not make clear what purpose the clause was intended to serve. ${ }^{12}$ Though some congressmen felt that it was so uncertain as to be a wider loophole than that which the courts had read into the restraint-of-trade provision of the Sherman Act,, ${ }^{13}$ Representative Webb, who was floor leader for the bill, thought that the law "will catch him [an exclusive-dealing seller] if he does it in one instance against one individual."14 Asked point-blank, "when you have proven the actual fact of discrimination, how much more will you have to prove in order to prove that he has substantially lessened competition and done that which tends to

${ }^{8}$ Tbid., at 229. Quoted by Representative Floyd, 51 Cong. Rec. 16,318 (1914).

- Consult Henderson, The Federal Trade Commission 40-44 (1924). Webster's New International Dictionary (2d ed., 1947) defines "substantial" as "consisting of, pertaining to, of the nature of. ..." "[N] ot seeming or imaginary; not illusive; real" is the second definition listed, while "considerable in amount" is the seventh.

10 "Incidentally" can have a quantitative meaning, but in the opinion it was later used in opposition to "directly." Addyston Pipe \& Steel Co. v. United States, 175 U.S. 211, 234 (1899). "Substantially" is used with quantitative connotation elsewhere in the opinion, "where the natural and direct effect of such a contract will be ... to directly . . . regulate to any substantial extent interstate commerce." Ibid., at 228.

${ }^{11}$ Which Representative Floyd apparently thought would have been required had the statute retained its criminal penalties. Consult page 234 supra.

${ }^{12}$ Although much of the debate related to Section 2, which prohibited price discrimination, it is clear that the qualifying clause was intended to have the same meaning wherever it was used in the Clayton Act. Representative Floyd said that the change had been made so "that the three sections, namely sections 2,3 and 7 of the conference report, are in harmony now, all dealing with the question of contracts, the same principle being applied to each one of them." 51 Cong. Rec. 16,318 (1914).

${ }^{13} 26$ Stat. 209 (1890), as amended, 15 U.S.C.A. $\$ 1$ (1951). 51 Cong. Rec. 16,324 (1914).

14 51 Cong. Rec. 16,341 (1914). 
monopoly?" he replied, "You do not have to prove either one..$^{15}$ You will only have to prove such a discrimination as may be to substantially lessen competition or may tend to create monopoly."16 This statement could indicate (1) that proof of an effect on competition would be required, (2) that a probable, rather than an actual, effect would have to be shown, or (3) that the qualifying clause was to have no effect other than to negate the need for proof of intent and purpose.

In the Senate, extensive objections were made to the new clause. Senator Reed, who understood "substantially" in a quantitative sense," also felt that the loophole was worse than the court's "unreasonable" requirement for the Sherman Act. ${ }^{18}$ Senator Walsh, who was Senate floor manager, replied that "substantially" was not an important word:

If it were out, the language would receive the same construction, because no court would find that competition was lessened unless it was "substantially" lessened. The Sherman Act denounces all combinations in restraint of commerce, but no combination falls under the ban of the statute unless commerce is restrained to a "substantial" extent. De minimis non curat lex.

The Senator apparently interpreted "substantially" as a quantitative jurisdictional requirement that would have to be satisfied before any court would consider the question of whether the statute had been violated. His example of substantiality came from "the Union Pacific-Southern Pacific case, ${ }^{10}$ in which the traffic affected by the combination amounted only to eighty-eight one-hundredths of 1 per cent of the total tonnage of the Southern Pacific."20

This jurisdictional interpretation could hardly mean that a "substantial" amount was intended as the dividing line beyond which the use of exclusive dealing would be illegal. Discarding this possibility, two other possible interpretations remain for the meaning of the qualifying clause as a whole. Arguably, it was meant to have the negative effect of preventing the courts from requiring proof of intent and purpose and for that purpose only. Under this interpretation, the results of exclusive dealing would have been defined by Congress as being restrictive of competition and exclusive dealing would be per se illegal. ${ }^{21}$ On the other hand, it is evident that many congressmen felt that "where the effect" meant exactly what it said and that proof

. ${ }^{15}$ "Either one" apparently refers to intent and purpose.

${ }^{16} 51$ Cong. Rec. 16,341 (1914).

${ }^{17}$ "The line of commerce, taken as a whole, must be substantially involved." Ibid., at 15,830 .

${ }^{18}$ Ibid., at 15,857 .

${ }^{19}$ United States v. Union Pacific R. Co., 226 U.S. 61 (1912).

${ }^{20} 51$ Cong. Rec. 16,149 (1914).

"II Under this interpretation, the "effect" clause would be satisfied by the very nature of the contract and not by the competitive repercussions of its existence. 
would be required of the restrictive effect on commerce that exclusive dealing might ${ }^{22}$ have. In any case, the courts have given a positive, if uncertain, effect to the qualifying clause. ${ }^{23}$

\section{II}

Prior to the Supreme Court's decision in Standard Stations, ${ }^{24}$ exclusivedealing arrangements had been struck down only when they involved a seller who dominated the market. ${ }^{25}$ The rationale of the courts was that exclusive dealing by such a seller would foreclose his competitors (present and potential) from the dominated segment of the market. The decisions have not further analyzed the foreclosure concept in terms of just why foreclosure is an economic ill. ${ }^{26}$ Though some commentators have advocated a more complete analysis, ${ }^{27}$ apparently on the thesis that exclusive dealing, without more, is not a detriment to competition, the courts seem to have concluded that the "probable" standard of proof dictated by Section 3 does not require a more rigorous analysis. ${ }^{28}$ Foreclosure, however, can exist in degrees varying from a "de minimis" requirement that indicates per se illegality to complete monopoly. ${ }^{29}$ Within this range, the illegality of exclusive dealing must begin at some point.

In the first major Section 3 case, Standard Fashion Co. v. Magrane Houston Co. ${ }^{30}$ the exclusive-dealing contracts of the supplier to 40 per cent of the nation's garment pattern distributors were held unenforceable because they violated Section 3. The Supreme Court's reference to the seller's dominant position $^{31}$ indicated that it was concerned with the possibility that foreclosure

"Might," since the statute requires only that the effect "may be." While a present adverse effect is sufficient to satisfy the statute, it does not require proof of any present harm, but only that harm will probably result.

${ }^{2}$ See page 238 and notes $32-34$ infra. 2. 337 U.S. 293 (1949).

$\approx$ This was Mr. Justice Frankfurter's statement of the situation in Standard Stations, ibid., at 301.

${ }^{26}$ The assumption seems to be that foreclosure signifies a monopolization of the segment foreclosed and that this is detrimental to competition. Consult Yankwich, Competition, Real or Soft, 14 F.R.D. 199, 213 (1953); Stevens, Unfair Competition 97 (1917); Clark and Clark, The Control of Trusts 98-103 (2d ed., 1912).

${ }^{n}$ Lockhart and Sachs, The Relevance of Economic Factors in Determining Whether Exclusive Arrangements Violate Section 3 of the Clayton Act, 65 Harv. L. Rev. 913 (1952); Stockhausen, The Commercial and Anti-Trust Aspects of Term Requirements Contracts, 23 N.Y.U.L.Q. Rev. 412 (1948).

${ }^{28}$ See page 238 infra.

$\infty$ There are two aspects of foreclosure: (1) the percentage of the market shut off, and (2) the completeness with which it is shut off. This comment will consider only the former, assuming that the latter, in most instances, is absolute.

${ }^{30} 258$ U.S. 346 (1922).

11 "[The courts below] put special stress upon the fact that, of the 52,000 so-called pattern agencies in the entire country, the petitioner .... approximately controlled two- 
of such a large segment of the market might result in an eventual monopoly for Standard Fashions ${ }^{32}$ - a conclusion based partially on consideration of the surrounding circumstances in this particular market. In analyzing the statute, the Court construed the qualifying clause as requiring only an inference of probable harm, stating:

But we do not think the purpose in using the word "may" was to prohibit the mere possibility of the consequences described. It was intended to prevent such agreements as would under the circumstances disclosed probably lessen competition, or create an actual tendency to monopoly. That it was not intended to reach every remote lessening of competition is shown in the requirement that such lessening must be substantial. ${ }^{33}$

By requiring a positive inference of probable harm in order to show illegality, this interpretation meant that the qualifying clause was to have more than the negative effect of making proof of intent and purpose unnecessary. The further effect of this construction was to dictate to later courts that proof of actual competitive detriment would not be required, so long as the circumstances (of which dominance was chief and perhaps sole) showed probability of such a result. ${ }^{34}$

Standard Fashions remained the authoritative exclusive-dealing holding until the Court's decision in Standard Stations. ${ }^{35}$ Standard Oil sold 23 per cent of the gallonage retailed in the seven-state western area; 6.7 per cent of the total gallonage was retailed through requirements contracts with 16 per cent of the area's dealers. Further, the western "Big Seven," all of whom had exclusive-dealing arrangements, sold 56 per cent of the area's retail service station gallonage. Because the Court, in comparing the facts to those of International Salt Co. v. United States, ${ }^{36}$ emphasized Standard Oil's 6.7 per cent of the total gallonage, yielding some $\$ 58,000,000$ a year, those figures could be taken as the quantitative measurement required by the Court's statement that "the qualifying clause of Section 3 is satisfied by proof that

fifths. . . "Ibid., at 357. McLaren, Related Problems of "Requirements" Contracts and Acquisitions in Vertical Integration Under the Anti-Trust Laws, 45 IIl. L. Rev. 141 (1950), argues that the economic analysis was broader than the mere fact of dominance, and that the case cannot stand for the proposition that dominance alone is sufficient to create illegality.

$$
\$ 2258 \text { U.S. } 346,357 \text { (1922). }
$$

${ }^{23}$ Ibid., at 356-57.

"The court refused to give weight to the intent of Congress, whatever that may have been, since "the words of the act are plain and their meaning is apparent without . . . extraneous statements. ... ." Ibid., at 356.

${ }^{35}$ Cf. Fashion Originators' Guild v. Trade Commission, 312 U.S. 457 (1941). But cf. Pick Mfg. Co. v. General Motors Corp. 80 F. 2d 641 (C.A. 7th, 1935), aff'd per curiam 299 U.S. 3 (1936). The Pick case was probably overruled by Standard Stations, though the Court failed to say so.

${ }^{38} 332$ U.S. 392 (1947). 
competition has been foreclosed in a substantial share of the line of commerce affected." 37 The result would be to make exclusive dealing illegal whenever it surpassed a merely "de minimis" quantitative requirement. The reasoning of the opinion, however, seems to negate the conclusion that these figures were the only ones relied on.

Supplied with the above facts, Mr. Justice Frankfurter set out to find whether the qualifying clause "may be met simply by proof that a substantial portion of commerce is affected or whether it must also be demonstrated that competitive activity has actually diminished or probably will diminish."38 Because requirements contracts could "be of economic advantage to buyers as well as sellers . . . coverage by such contracts of a substantial amount of business affords a weaker basis for the inference that competition may be lessened than would similar coverage by tying clauses. . . ."39 Hence, "certainly as a matter of economic reasoning, varying standards as to each for the proof necessary to fulfill that clause"40 might be used. He found, however, that the theoretically relevant items would be inconclusive because "[w] it is remembered that all the other major suppliers have also been using requirements contracts, and when it is noted that the relevant share of the business which fell to each has remained about the same during the period of their use, it would not be farfetched to infer that their effect has been to enable the established suppliers individually to maintain their own standing ${ }^{41}$ and at the same time collectively, even though not collusively, to prevent a late arrival from wresting away more than an insignificant portion of the

${ }^{37}$ United States v. Standard Oil Co., 337 U.S. 293, 314 (1949).

${ }^{28}$ Ibid., at 299.

30 Ibid., at 306-7. The tying arrangement is the other practice proscribed by Section 3. The unfortunate phrasing of Section 3 , however, does not specifically cover the usual tiein, since the agreement is one in which the buyer (or lessee) of the tying product agrees only not to use competitor's goods in conjunction with the tying product, rather than agreeing not to buy the competitor's goods at all. Tying agreements were held to be within the intention of the statute, however, in United Shoe Mach. Co. v. United States, 258 U.S. 451, 457 (1922), because the practical effect of requiring the use of United Shoe's tied machines in order to obtain the tying machines over which United Shoe had a patent monopoly was to prevent the lessee from taking any machines from other manufacturers. Under this effect analysis, the statute is satisfied whenever the seller has a monopoly or market dominance over the tying product. Cf. International Salt Co. v. United States, 332 U.S. 392 (1947), where the lessor also had a patent on the tying product. Consult Henderson, op. cit. supra note 9, at 302-11. This faulty phrasing could explain FTC v. Sinclair Refining Co., 261 U.S. 463 (1923), where gasoline pumps were leased on condition that they be used only with the lessor's gasoline. Since the lessee could obtain pumps elsewhere (i.e., since Sinclair did not dominate the pump market) and could sell other gasoline in them, Section 3 was not violated by the tying agreement. See, generally, Lockhart and Sachs, op. cit. supra note 27 , at 942-54.

10 337 U.S. 293, 307-8 (1949).

"1 "Standing" is presumably meant in a percentage share of the market sense, and not in the sense of the dollar volume of business remaining the same. 
market." 42 Hence, the originally weak inference that competition might be lessened, reinforced by the use of requirements contracts by a group of major suppliers, created an inference strong enough to satisfy the qualifying clause.

In evaluating the inference, Mr. Justice Frankfurter denied the need for a "firm prediction of an increase in competition." think it would be both impossible and useless to try to discover whether a market in which exclusive dealing was permitted would enjoy less competition than one in which exclusive dealing was forbidden but other anti-competitive devices could still be used. The ability to deter competition by foreclosing others from a major share of the market thus seems to have been the "probable" effect found in Standard Stations. Because no single seller had the dominance to foreclose such a section of the market by himself, resort was had to the collective, though not collusive, use of exclusive dealing by a group of major sellers. Whether this interpretation of the case or that which emphasized the almost "de minimis" requirement of 6.7 per cent of the gallonage was authoritative remained for the later cases to decide.

\section{III}

United States v. American Can Co. ${ }^{44}$ gave the lower federal courts their first opportunity to construe Standard Stations. American Can, producer of 46 per cent of the nation's cans, had pursued a policy of leasing its expensive closing machines at nominal rentals to those users who signed five-year requirements contracts for their cans. In a prosecution under Sections 1 and 2 of the Sherman Act and Section 3 of the Clayton Act, this policy was termed a tying agreement and found in violation of Section 3. The criterion for effect on competition was "foreclos[ure] in a substantial share of the line of commerce affected." 45 Apparently disregarding Standard Stations, the court went on to hold that the requirements contracts themselves, when separated from the closing machines, were not within the terms of Section 3, since they denoted quantity to be purchased and not conditions of the contract. ${ }^{46}$ Because of this conclusion, the case is not authority for the standard of proof in exclusive-dealing cases under the Clayton Act. The five-year term of the contracts, however, was found to be violative of the Sherman Act as unreasonably restrictive of competition and was cut to a one-year maximum.

Judge Yankwich, who had rendered the district-court decision affirmed in

¿2337 U.S. 293, 309 (1949).

${ }^{2}$ Tbid., at 310 .

487 F. Supp. 18 (N.D. Calif., 1949).

${ }^{4} \mathrm{Ibid}$, at 27 . The standard for tying contracts is only that they not be insignificant in amount. International Salt Co. v. United States, 332 U.S. 392 (1947).

${ }^{48} 87$ F. Supp. 18, 32 (N.D. Calif., 1949). The reason is supplied in defendant's brief, cited but not quoted by the court. But cf. United States v. Richfield Oil Corp., $99 \mathrm{~F}$. Supp. 280, 295 (S.D. Calif., 1951), aff'd per curiam 343 U.S. 922 (1952). 
Standard Stations, made it quite clear in United States v. Richfield Oil Corp. ${ }^{47}$ that he had meant "substantially" as no more than a "de minimis" requirement. The major problem in Richfield Oil was to obviate defendant's contention that its stations not only dealt exclusively with Richfield, but were so clearly within the control of Richfield as to be agencies and thus not within the coverage of Section $3{ }^{48}$ Richfield leased stations to the operators, the latter agreeing to deal exclusively or, in some cases, to buy a given quantity of gasoline. The leases contained a twenty-four-hour termination clause $^{49}$ and sometimes a painting agreement, ${ }^{50}$ both of which were used to force Richfield dealers to handle only Richfield products. Judge Yankwich found that each of the arrangements was, in effect, an exclusive-dealing agreement with operators who were sufficiently independent to come within Section 3. Standard Stations then served as a shorthand explanation of the illegality of the arrangements. Comparative statistics of Richfield's share of the market were not considered since " $t \mathrm{t}]$ he agreements affect a substantial number of outlets and a substantial amount of products, whether considered comparatively or not."ssi

Because the district-court opinion contained no estimate of Richfield's market position, the Supreme Court's per curiam affirmance seemed to indicate that the "not insignificant or insubstantial" quantitative measurement used in International Salt Co. v. United States, ${ }^{52}$ a tying-contract case, had been adopted by the Court in exclusive-dealing cases as well. However, since the exclusive-dealing agreements were tied to and enforced through the dealer's leases, the Richfield case itself could be explained as a tying-contract case. As such, it could legitimately come under the International Salt doctrine and would not be indicative of the criteria of legality for exclusivedealing cases.

${ }^{47} 99$ F. Supp. 280 (S.D. Calif., 1951), aff'd per curiam 343 U.S. 922 (1952).

${ }^{4}$ FTC v. Curtis Publishing Co., 260 U.S. 568 (1923).

6 The twenty-four-hour termination clause did not create a short-term exclusive-dealing contract, since it terminated not the sales contract but the property lease. It was used to force buyers to deal exclusively, or risk being put out of business.

${ }^{50}$ Richfield paid for painting the stations. If the contract was breached, however, the operator was obligated to reimburse Richfield for the cost of the painting.

99 F. Supp. 280, 297 (S.D. Calif., 1951), aff'd per curiam 343 U.S. 922 (1952). Contrast the quantitative interpretation in Sunset Oil Co. v. Vertner, 34 Wn. 2d 268, 208 P. 2d 906 (1949), where a retail operator failed in his attempt to defend the breach of his exclusive-dealing contracts on the ground that they violated Section 3 . Since he introduced only his contracts, he did not come within the quantitative requirements of the substantiality test. One who has refused to buy on exclusive-dealing terms apparently does not have a cause of action either. Nelson Radio \& Supply Co. v. Motorola, Inc., 200 F. 2d 911 (C.A. 5th, 1952), cert. denied 345 U.S. 925 (1953), where recovery was denied even though the court assumed that defendant's use of exclusive-dealing contracts was unlawful.

82332 U.S. 392,396 (1947). Consult note 34 supra. 
Before turning to the Supreme Court's latest pronouncement on the standard of legality for Section 3, one more important lower-court decision remains to be considered. In United States v. J. I. Case Co.,.$^{53}$ the government sought to prove that Case imposed exclusive dealing on its dealers, in violation of Sections 1 and 2 of the Sherman Act and Section 3 of the Clayton Act. ${ }^{54}$ Because Case had no contractual exclusive-dealing arrangements, the government resorted to evidence of coercive practices and refusals to sell to dealers who also carried the farm implements of other manufacturers. Such evidence was produced as to 108 of Case's 3,700 dealers. The court found, however, that the evidence failed to show that the dealers had really agreed not to buy the products of others; rather, there was "an abundance of evidence that the exclusivity of Case dealers is a matter of the dealer's volition ${ }^{55}$ in most instances, or recognition by both the dealer and the manufacturer that good business practices suggest such an arrangement." 56

The court did add an interesting dictum on the substantiality question. Since the government relied on only 108 of the nation's 20,000 farm-equipment dealers (one-half of one per cent), the court was unwilling to say that competition could be substantially lessened ${ }^{57}$ Though this is even less than Senator Walsh's "de minimis" requirement, ${ }^{58}$ the court was evidently thinking in terms of a standard approximating Standard Oil's 16 per cent of the dealers.

The most important commentary on the "de minimis" interpretation of Standard Stations came in FTC v. Motion Picture Advertising Co. (MPA).59 The majority opinion held, under Section 5 of the FTCA, that MPA's exclusive-dealing contracts for the sale of advertising films to theaters should be limited to one year. Its decision was based on a finding that MPA's exclusive-dealing contracts, together with those of three other distributors, had foreclosed some 75 per cent of the market to competitors and thus violated

53101 F. Supp. 856 (D. Minn., 1951).

st Because of the different standards under the two acts, it is important to differentiate the kinds of evidence adduced in terms of the ultimate facts required by each statute.

w "Volition" is used in the sense that the dealers bought only from Case because this was good business and not because the dealers were willing to agree to buy only from Case.

${ }^{56} 101$ F. Supp. 856, 866 (D. Minn., 1951). The court's conclusion means that, on the facts, Case and its dealers simply did not engage in the practices proscribed by Section 3.

${ }^{57}$ Because the government had interrogated some 4,854 present and former Case dealers and still alleged exclusive dealing as to only 108, the court was apparently unwilling to infer that the 108 were evidence of the probability of such practices with a larger number of dealers. Ibid., at 859 .

${ }^{\text {ss }}$ Authority cited note 20 supra. It would not be insignificant in dollar amount under the International Salt doctrine.

${ }^{50} 344$ U.S. 392 (1953). 
the Sherman Act. ${ }^{60}$ Such actions could be struck down under the FTCA which was designed to nip Sherman Act violations in their incipiency. Mr. Justice Frankfurter, in dissent, felt that the collective-though-not-collusive concept was not an appropriate measure of a Sherman Act violation; only actual conspiracy would be relevant in such an action. ${ }^{61}$ Alternatively, he did not feel that the agreements could be struck down on the basis of their being either a present or an incipient Clayton Act violation; not the latter since the FTCA was not designed to reach incipient Section 3 violations; ${ }^{62}$ not the former since the commission had failed to make clear the criteria which it had used to adjudge MPA's exclusive dealing unlawful. ${ }^{63}$ In the light of Standard Stations, ${ }^{64}$ he thought the Court should have been appraised of the percentage of the market shut off and the aggregate volume of business affected. Desire to have these factors before the Court does not indicate which of the two interpretations of Standard Stations Mr. Justice Frankfurter felt should be used as the standard of Section 5 actions. He could not agree with the majority's 75 per cent figure, since it was unclear how many of the contracts ran for more than the one-year term the commission had found acceptable. Though the figures about which Mr. Justice Frankfurter did speculate related only to MPA's share of the market, ${ }^{65}$ he rejected the collective-though-not-collusive concept only because it was not applicable to an action based on a Sherman Act violation, specifically admitting its relevance in the light of Standard Stations. ${ }^{66}$ Thus, the dissent's rejection of Standard Stations as a precedent need not indicate a deviation from the foreclosure analysis noted earlier; in fact, the references to Standard Oil's position in the market and the need for a showing of the percentage of the market shut

${ }^{\infty}$ Ibid., at 395 .

or "While the existence of the other exclusive contracts is, of course, not irrelevant in a market analysis, see Standard Oil Co. v. United States, 337 U.S. 293, 309, this Court has never decided that they may, in the absence of conspiracy, be aggregated to support a charge of Sherman Law violation." Ibid., at 399-400.

62 "But it is another thing to suggest that anything in business activity that may, if unchecked, offend the particularizations of the Clayton Act may now be reached by the Federal Trade Commission Act." Ibid., at 405. The similarity of scope of the two acts, expressed in the congressional debates, would seem to reinforce this argument. See note 4 supra.

Co Ibid., at 398 and 401.

"Since the party bound to deal exclusively was the seller of screen space and not the buyer, the action could not have been brought under Section 3. Mr. Justice Frankfurter, however, assumed that Standard Stations was an expression of public policy underlying Section 5. As such, it did not control. Thid., at 401.

${ }^{\infty}$ Ibid., at 399.

${ }^{\infty 6}$ Consult note 61 supra. 
off tend to reinforce that interpretation, as does the majority's reliance on the finding that MPA, with three others, "ha[d] foreclosed to competitors 75 per cent of all available outlets. . . ."7t

\section{IV}

It thus seems that the courts have continued to apply a foreclosure analysis to exclusive-dealing cases, but with the modification that sufficient foreclosure can now be provided not only by a dominant seller but by the collective, though not collusive, use of exclusive dealing by a group of sellers. It is true that the latter concept loses its validity if applied to a market in which all of the sellers are quite small, since it is quite likely that competition will be flourishing in such a situation. And in the cases, the collective-though-notcollusive concept has, so far, been limited to those situations in which it is used by a group of major, even though not individually dominant, sellers, and in which the presence of effective competition is less probable.

The decisions do not indicate that a more rigorous attempt to analyze the market situation will be made ${ }^{68}$ - a result probably prompted by the language of Section 3 of the Clayton Act. The majority opinion in MPA suggests, however, an additional factor that could be considered consistently with the foreclosure analysis: the term of the arrangement. ${ }^{69} \mathrm{~A}$ similar result was reached by the FTC under Section 3 in Dictograph Products, Inc..$^{70}$ Dictograph had exclusive-dealing agreements with some 220 of the estimated 1,000 hearingaid distributors, ${ }^{71}$ the contracts terminable at any time by either party but with a proviso that upon termination the distributor must refrain from doing business for one year within the territory assigned to him. This meant that no dealer would terminate or risk termination by breach of the exclusive-

${ }^{\theta 7} 344$ U.S. 392, 395 (1953).

${ }^{69}$ At least two commentators have advocated a broader analysis. Authorities cited note 27 supra. In addition, the FTC has indicated that it will hear evidence of an increased number of competitors and a decline in the defendant's share of the market as a defense in Section 3 actions. The Maico Co., CCH Trade Reg. Rep. I11,577 (FTC, 1953). The commission's argument that the Standard Stations opinion authorized them to take such a position is doubtful. It is based on a footnote in that opinion, Standard Oil Co. v. United States, 337 U.S. 293, 310 n. 13 (1949).

${ }^{\oplus}$ The foreclosure that exclusive dealing creates exists only for the term of the arrangement. If the contracts are for a short term, the buyer and the seller's competitors are free to negotiate in anticipation of the frequent intervals when the buyer will be free to change sellers.

${ }^{\text {70 }} \mathrm{CCH}$ Trade Reg. Rep. I11,526 (FTC, 1953).

7 Though not stated in the opinion, the filing of complaints against The Maico Co., Dkt. 5822, Beltone Hearing Aid Co., Dkt. 5825, and Dictograph Products, Inc., Dkt. 5655 , all major producers, indicates that an even larger share of the distributor market, from the newcomer's point of view, was foreclosed to competition. 
dealing provision; the term of the contracts thus tended toward infinity. ${ }^{72}$ The commission, in finding the exclusive dealing violative of both Section 3 and Section 5, emphasized the factors of size and term, stating that the qualifying clause of Section 3 was satisfied "where one of the largest producers in the field has tied up a substantial portion of the established retail outlets with exclusive dealing contracts containing such termination provisions."73

With the exception of the term factor, however, the foreclosure concept seems to have precluded more extensive economic analysis. Factors such as the availability of new buyers, which relate to the degree of detriment to other sellers caused by exclusive dealing, ${ }^{74}$ have not been considered by the courts. The rejection can be justified by the "probable" standard of proof dictated by Section 3 . If one rejects the notion that the statute was intended to make exclusive dealing per se illegal, recourse can be had only to the qualifying clause to determine the criteria of illegality. The concept the courts have applied to that clause has been that of foreclosure. Interpreting foreclosure as a "de minimis" requirement again approaches per se illegality. The cases indicate, however, that something more than "de minimis" foreclosure has been necessary: use of exclusive dealing by a dominant seller or by a group of major sellers seems to be necessary before the arrangement will be struck down. An additional factor, that of term, does seem to be available to the foreclosure analysis, since whatever detrimental effects exist continue for only a limited time. Short-term foreclosure hardly seems to admit of even the probable economic detriment that the courts have posited as necessary to invoke Section 3.

Such a standard of illegality represents the attempt of the courts to apply Section 3 to a method of doing business that was felt to be undesirable by the legislators of 1914 , but whose actual economic consequences are unclear. Though Congress arguably meant to make exclusive dealing per se illegal, it has thus far been invalidated only when used by a dominant seller or by a group of major sellers. Considering the apparent merits of exclusive dealing, especially when cast in requirements form, as a method of doing business, the rejection of the per se standard seems desirable. The presence of the statute makes some standard necessary, however, and perhaps the foreclosure analysis yields a workable compromise between the needs of business and the demands of the language of Section 3 of the Clayton Act.

\footnotetext{
${ }^{72}$ The dealers in question specialized in the sale of hearing aids. The exclusion-frombusiness proviso meant that they would, upon termination, have to shift to a completely new business. Dictograph Products, Inc., CCH Trade Reg. Rep. I 11,526 at 12,504 (FTC, 1953).

Ibid.

"In terms of the market available to the seller, such factors relate to the effectiveness of the foreclosure.
} 